\title{
Degradation of Poly( $\varepsilon$-caprolactone) by thermophilic Streptomyces thermoviolaceus subsp. thermoviolaceus 76T-2
}

\author{
Te-Kuan Chua ${ }^{1}$, Min Tseng ${ }^{2}$ and Mei-Kwei Yang ${ }^{1 *}$
}

\begin{abstract}
A thermophilic Streptomyces thermoviolaceus subsp. thermoviolaceus isolate 76T-2 that can degrade poly( $\varepsilon$ caprolactone) (PCL) was isolated from soil in Taiwan. Isolate 76T-2 grew well in urea fructose oatmeal medium and exhibited clear zones on agar plates containing $\mathrm{PCL}$, indicating the presence of extracellular $\mathrm{PCL}$ depolymerases. The PCL powder present in culture medium was completely degraded within $6 \mathrm{~h}$ of culture at $45^{\circ} \mathrm{C}$. Two PCL-degrading enzymes were purified to homogeneity from the culture supernatant. The molecular weights of these two enzymes were estimated to be $25 \mathrm{kDa}$ and $55 \mathrm{kDa}$, respectively. A portion of the $\mathrm{N}$-terminal region of the 25-kDa protein was determined, and the sequence Ala-Asn-Phe-Val-Val-Ser-Glu-Ala thus obtained was identical to that of $A_{64}-A_{71}$ of the Chi25 chitinase of Streptomyces thermoviolaceus OPC-520. The 25-kDa protein was shown to also degrade chitin, suggesting that isolate 76T-2 has the ability to degrade both PCL and chitin.
\end{abstract}

Keywords: Poly(E-caprolactone) (PCL), Streptomyces thermoviolaceus subsp. thermoviolaceus, PCL depolymerases, Chi25 chitinase

\section{Introduction}

Polycaprolactone (PCL), a biodegradable synthetic aliphatic polyester, is a polymer of $\varepsilon$-caprolactone (Tokiwa et al. 1976, Tokiwa and Suzuki 1977, Benedict et al. 1983a). Due to its favorable physical properties such as low melting point $\left(60^{\circ} \mathrm{C}\right)$, low glass transition temperature $\left(-60^{\circ} \mathrm{C}\right)$, hydrophobicity, and crystallinity which resemble those of conventional plastics, PCL is being used as a biodegradable substitute for non-degradable plastics (Tokiwa and Calabia 2004, Tokiwa et al. 2009). Since PCL is thermostable and biocompatible for tissue engineering, drug release, and wound dressing, it has a great potential in industrial and medical applications (Sinha et al. 2004, Lenz and Marchessault 2005, Sun et al. 2006, Shah et al. 2008).

Degradation of PCL may take place in soil, water, and compost by microorganisms (Tokiwa et al. 1976, Nishida and Tokiwa 1993, Klingbeil et al. 1996, Abou-Zeid et al. 2001, Ponsart et al. 2001, Federle et al. 2002, Abou-Zeid et al. 2004, Nakasaki et al. 2006, Tokiwa et al. 2009). Most PCL-degrading fungi are found in genera Penicillium and

\footnotetext{
* Correspondence: 002327@mail.fju.edu.tw

${ }^{1}$ Department of Life Science, Fu Jen University, Hsin Chuang, Taipei, Taiwan Full list of author information is available at the end of the article
}

Aspergillus (Tokiwa et al. 1976, Benedict et al. 1983b, Sanchez et al. 2000), and most PCL-degrading bacteria belong to the genus Clostridium (Abou-Zeid et al. 2001, 2004). A thermophilic Streptomyces isolated from compost was found to have a higher PCL-degrading activity than thermotolerant Aspergillus (Nakasaki et al. 2006). Since composting at high temperature is an ideal method for recycling biodegradable plastics by thermophilic microorganisms (Tokiwa et al. 2009), isolation of thermal resistant PCL-degraders is desired.

Among the various thermophilic microorganisms, some actinomycetes have been shown to produce enzymes that hydrolyze polyesters at high temperature (Klingbeil et al. 1996, Calabia and Tokiwa 2004, Tokiwa and Calabia 2004). We have isolated many polyester-degrading thermophilic actinomycetes from different environments in Taiwan (Tseng et al. 2007). Some of them can degrade either polyhydroxybutyrate (PHB), PCL, or polyethersulfone (PES); others can degrade two or all three of these polyesters. Among the 198 PCL-degrading actinomycetes we have isolated, Streptomyces thermoviolaceus subsp. thermoviolaceus 76T-2, isolated from soil, has the highest growth and PCL hydrolysis rates. To be able to use it in an industrial 
scale, we characterized the organism and purified the PCL-degrading enzymes from this organism.

\section{Materials and methods}

Screening of PCL-degrading thermophilic actinomycetes

Thermophilic actinomycetes were isolated from soil samples as described previously (Tseng et al. 2007). The samples were plated on modified $\mathrm{HV}$ agar plates (humic acid, 1.0 g; yeast extract, 3.0 g; $\mathrm{KCl}, 1.7$ g; $\mathrm{FeSO}_{4} \cdot 7 \mathrm{H}_{2} \mathrm{O}$, 0.01 g; $\mathrm{Na}_{2} \mathrm{HPO}_{4}, 0.5$ g; $\mathrm{MgSO}_{4} \cdot 7 \mathrm{H}_{2} \mathrm{O}, 0.05 \mathrm{~g} ; \mathrm{CaCO}_{3}$, $0.02 \mathrm{~g}$; cycloheximide, $50 \mathrm{mg}$; nalidixic acid, $20 \mathrm{mg}$; $0.5 \mathrm{mg}$ each of thiamine- $\mathrm{HCl}$, riboflavin, niacin, pyridoxine- $\mathrm{HCl}$, inositol, Ca-pantothenate, p-aminobenzoic acid, and $0.25 \mathrm{mg}$ of biotin; agar, 18.0 g; distilled water $1 \mathrm{~L}$, $\mathrm{pH}$ 7.2), and the plates were incubated at $45^{\circ} \mathrm{C}$ for 7-10 days. The powdery colonies with branched hyphae on the plates were then picked and streaked on International Streptomyces Project (ISP) 3 agar plates (oatmeal, 20 g; $1 \mathrm{mg}$ each of $\mathrm{FeSO}_{4} \cdot 7 \mathrm{H}_{2} \mathrm{O}, \mathrm{MnCl}_{2} \cdot \mathrm{H}_{2} \mathrm{O}$ and $\mathrm{ZnSO}_{4} \cdot 7 \mathrm{H}_{2} \mathrm{O}$; agar, $18 \mathrm{~g}$ in $1 \mathrm{~L}$ of distilled water, $\mathrm{pH}$ 7.2) and incubated at $45^{\circ} \mathrm{C}$ for 3-7 days for identification. The PCL-degradation ability of the isolates was detected by the presence of a clear zone around the colonies on agar plates containing emulsified PCL. PCL agar plates were made by dissolving one gram of PCL powder in $50 \mathrm{ml}$ of methylene chloride and then emulsified into $50 \mathrm{ml}$ basal medium containing (per liter) yeast extract, $0.1 \mathrm{~g} ; \mathrm{FeSO}_{4} \cdot 7 \mathrm{H}_{2} \mathrm{O}, 10 \mathrm{mg}$; $\mathrm{MgSO}_{4} \cdot 7 \mathrm{H}_{2} \mathrm{O}, 0.2 \mathrm{~g}$; $\left(\mathrm{NH}_{4}\right)_{2} \mathrm{SO}_{4}, 1 \mathrm{~g} ; \mathrm{CaCl}_{2} \cdot 2 \mathrm{H}_{2} \mathrm{O}, 20 \mathrm{mg}$; $\mathrm{NaCl}, 0.1$ g; $\mathrm{Na}_{2} \mathrm{MoO}_{4} \cdot 2 \mathrm{H}_{2} \mathrm{O}, 0.5 \mathrm{mg} ; \mathrm{NaWO}_{4} \cdot 2 \mathrm{H}_{2} \mathrm{O}$, $0.5 \mathrm{mg} ; \mathrm{MnSO}_{4} \cdot \mathrm{H}_{2} \mathrm{O}, 0.6 \mathrm{mg}$; and dishwashing liquid, $1 \mathrm{ml}$ (Poas, Nice Co., Taiwan). Methylene chloride was then evaporated in a hume hood.

\section{Identification of PCL-degrading thermophilic actinomycetes}

To identify isolate 76T-2, scanning electron microscopy was first performed. After growth on oatmeal agar (ISP3 medium) plates at $45^{\circ} \mathrm{C}$ for 7 days, a representative colony was isolated, fixed in $4 \%$ osmium tetroxide, dehydrated through a graded ethanol series, dried to critical point, coated with gold, and then examined with a scanning electron microscope (Itoh et al. 1989). Morphological characteristics were assessed by using 7-day cultures grown at $45^{\circ} \mathrm{C}$ on yeast extract-malt extract agar (ISP 2 medium), oatmeal agar (ISP 3 medium), inorganic salts-starch agar (ISP 4 medium), and glycerol-asparagine agar (ISP 5 medium) (Shirling and Gottlieb 1966). The ISCC-NBS Color-Name Charts were used for color designations of substrate mycelium and aerial mass. 76T-2 cells for chemotaxonomic and molecular studies were harvested after incubation in yeast-glucose broth (yeast extract 1.0\%, glucose $1.0 \%, \mathrm{w} / \mathrm{v}$ ) for 7 days at $45^{\circ} \mathrm{C}$. Isomers of diaminopimelic acid (A2pm) and sugars in whole-cell lysates and cell walls were determined as described previously (Hasegawa et al. 1983).

\section{Phylogenetic analysis}

To determine the nucleotide sequence of the 16S rRNA gene, genomic DNA was extracted from 5-day cultured cells using the QIAGEN ${ }^{\circledR}$ Genomic DNA Kit. A portion of the $16 \mathrm{~S}$ rRNA gene was amplified by PCR as described by Nakajima et al. (Nakajima et al. 1999) and then sequenced directly on an ABI automatic DNA sequencer (Model 3730) using the BigDye Terminator V3.1 kit (Applied Biosystems). The resulting $16 \mathrm{~S}$ rDNA sequence was compared to the sequences obtained from the EzTaxon server (Chun et al. 2007) to identify 76T-2.

\section{Growth and PCL-degrading ability of S. thermoviolaceus subsp. thermoviolaceus 76T-2}

The growth characteristic was determined by growing 76T-2 cells in Luria Bertani (LB), UF (15 g of fructose, $10 \mathrm{~g}$ of peptone, $10 \mathrm{~g}$ of yeast extract, $2 \mathrm{~g}$ of urea, $20 \mathrm{mg}$ of $\mathrm{CaCl}_{2} \cdot 2 \mathrm{H}_{2} \mathrm{O}, 200 \mathrm{mg}$ of $\mathrm{MgSO}_{4} \cdot 7 \mathrm{H}_{2} \mathrm{O}$ in one liter of distilled water), and Urea Fructose Oatmeal (UFO) media. The optimal growth temperature was assessed using UF medium. For examination of PCL-degrading enzymes, 76T-2 cells were grown at $45^{\circ} \mathrm{C}$ in UF medium to stationary phase and then transferred to basal medium containing $0.1 \%(\mathrm{w} / \mathrm{v}) \mathrm{PCL}$ for various lengths of time. To assay extracellular PCL-degrading enzymes, aliquots of culture supernatant were assessed for the decrease in turbidity of the emulsified PCL. To quantify PCL-degrading activity, $1 \mathrm{ml}$ of an overnight liquid culture in UF medium was mixed with $20 \mathrm{ml}$ of basal medium containing 0.3\% PCL and incubated at $30-50^{\circ} \mathrm{C}$ for $14 \mathrm{~h}$. The PCL-degrading activity was measured spectrophotometrically at $650 \mathrm{~nm}$.

\section{Purification of PCL depolymerase}

For isolation of extracellular PCL depolymerases, 76T-2 cells were grown in basal medium containing PCL as carbon source at $45^{\circ} \mathrm{C}$ for $12 \mathrm{~h}$ with shaking. The cells were removed by centrifugation at $12,000 \mathrm{x}$ g for $20 \mathrm{~min}$ at $4^{\circ} \mathrm{C}$, and the supernatant was used for enzyme preparation. Crude enzymes were precipitated by adding solid ammonium sulfate with continuous stirring at $4^{\circ} \mathrm{C}$ for $1 \mathrm{~h}$ and then pelleted by centrifugation. The precipitate was dissolved in $50 \mathrm{mM}$ Tris- $\mathrm{HCl}$ buffer $(\mathrm{pH} 7.2)$ and dialyzed against four volumes of the buffer. Protein concentration was determined using the Lowry method with bovine serum albumin as a standard. Isolated enzymes were subjected to $10 \%$ sodium dodecyl sulfate-polyacrylamide gel electrophoresis (SDS-PAGE). PCL-degrading activity was detected by zymography by separating the proteins in a native polyacrylamide gel. After electrophoresis, the gel was placed on another polyacrylamide gel containing $0.1 \%$ PCL or chitin and incubated at $45^{\circ} \mathrm{C}$ for $30 \mathrm{~min}$. Active protein 
bands were detected as clear zones. The gel was then stained with Coomassie brilliant blue R-250 to determine the sizes of the proteins with PCL-degrading activity.

\section{Results}

Isolation and identification of PCL-degrading S. thermoviolaceus subsp. thermoviolaceus isolate 76T-2

One gram of each soil sample was suspended in $9 \mathrm{~mL}$ of sterilized distilled water. A serially diluted $0.1-\mathrm{mL}$ aliquot of each sample was plated on a modified HV agar plate and incubated at $45-50^{\circ} \mathrm{C}$ for $7-10$ days. Many powdery and irregular colonies with branched hyphae were seen in most cultures. Some of these isolates were found to degrade PCL when they were subcultured on oatmeal agar plates containing PCL, and an isolate designated 76T-2 was found to have the highest PCL-degrading activity .

Isolate 76T-2 produced round, pale white cottony colonies on oatmeal agar plates. Analyses of its peptidoglycan cell wall revealed that the major constituent was LL-diaminopimelic acid (LL-DAP). No sugars were detected. The cell wall was thus determined to be chemotype I (Lechevalier and Lechevalier 1970). Its aerial mass on ISP medium 4 was grayish-brown or grayish-purple, and substrate mycelia were brownish-black, light brown, or purplish-white. On ISP medium 2, isolate 76T-2 showed robust growth; rates of growth on ISP media 3, 4, and 5 were moderate. Sporulation of isolate 76T-2 on ISP medium 2 was good, moderate on ISP 3 and 5 media, but poor on ISP medium 4. Mature spore chains were spiralshaped with a warty surface (Figure 1). Based on these observations, isolate 76T-2 was considered a Streptomyces (Lechevalier and Lechevalier 1970). The 16S rRNA sequence of 76T-2 (GenBank accession no. KC470043) was aligned with those of Streptomyces and found to be $99.9 \%$ homologous to that of Streptomyces thermoviolaceus subsp. thermoviolaceus. The isolate Streptomyces thermoviolaceus subsp. thermoviolaceus 76T-2 (BCRC16931) has been deposited in the Bioresource Collection and Research Center, Food Industry Research and Development Institute, Hsinchu, Taiwan.

\section{Growth and PCL-degrading activity of S. thermoviolaceus subsp. thermoviolaceus isolate 76T-2}

76T-2 cells were cultured in UFO, UF, and LB media to determine their growth requirements. The cell density (absorbance at $650 \mathrm{~nm}$ ) and dried cell mass of the cultures were measured every two hours for 14 hours (Figure 2A). A rapid growth was observed after $2 \mathrm{~h}$, and the growth peaked after $12 \mathrm{~h}$ of incubation in all three media. Maximum growth was observed $\left(\mathrm{OD}_{650}=2.0\right.$, cell mass $=2.8 \mathrm{mg} / \mathrm{ml}$ ) after $12 \mathrm{~h}$ of incubation in UF medium at $40^{\circ} \mathrm{C}$ or $45^{\circ} \mathrm{C}$. A slower growth rate was seen after $12 \mathrm{~h}\left(\mathrm{OD}_{650}=1.6\right)$ and $24 \mathrm{~h}\left(\mathrm{OD}_{650}=1.7\right)$ of incubation at $50^{\circ} \mathrm{C}$. $76 \mathrm{~T}-2$ cells did not grow well

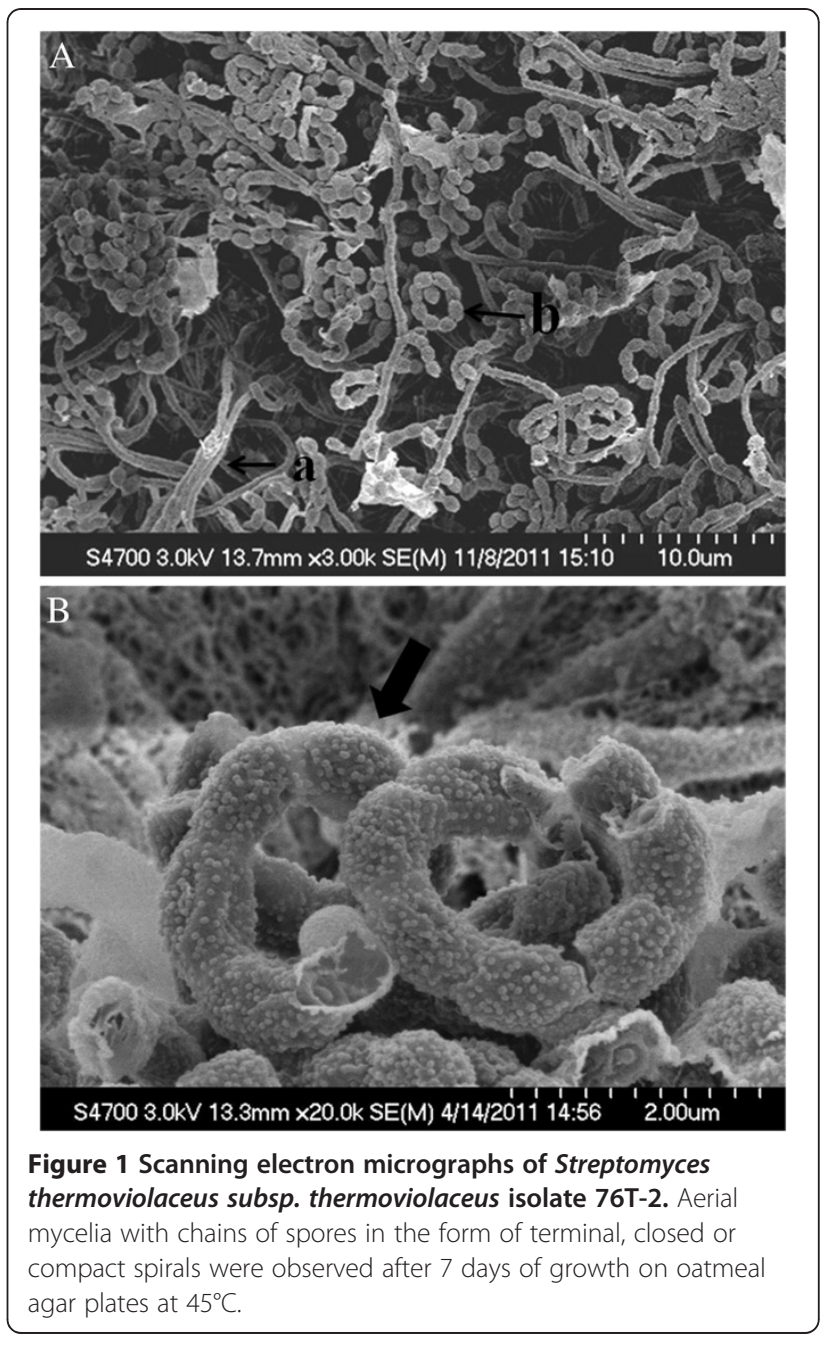

at $30^{\circ} \mathrm{C}$. These results (Figure 2B) suggest that the optimal growth temperature for $76 \mathrm{~T}-2$ is $45^{\circ} \mathrm{C}$.

The effect of temperature on PCL degradation by $76 \mathrm{~T}-2$ was then investigated. $76 \mathrm{~T}-2$ cells were grown in UF medium for $12 \mathrm{~h}$ at $45^{\circ} \mathrm{C}$ and then in basal medium containing $0.3 \% \mathrm{PCL}$ at a temperature between $30^{\circ} \mathrm{C}$ and $50^{\circ} \mathrm{C}$. The PCL hydrolytic activity was assayed every $2 \mathrm{~h}$ for $14 \mathrm{~h}$ by measuring the turbidity of the culture. Changes in PCL turbidity as indicated by $\mathrm{OD}_{650}$ values due to PCL degradation at various temperatures are shown in Figure 3. The hydrolysis of PCL was noticeable at the begining $\left(\mathrm{OD}_{650}=1.4\right)$ of culture and was maximal $\left(\mathrm{OD}_{650}=0.05\right)$ at $1 \mathrm{~h}$ of incubation when 76T-2 cells were grown at $40^{\circ} \mathrm{C}$. No further increase in PCL degradation was observed afterward.

At $45^{\circ} \mathrm{C}$, a lower degree of PCL hydrolysis $\left(\mathrm{OD}_{650}=0.95\right)$ was observed after $1 \mathrm{~h}$ of culture, but a significant degradation $\left(\mathrm{OD}_{650}=0.15\right)$ of PCL was seen at the $2 \mathrm{~h}$ time point. The PCL degradation reached the maximum $\left(\mathrm{OD}_{650}=0.05\right)$ after $4 \mathrm{~h}$ of incubation. A similar trend of PCL degradation was observed at $50^{\circ} \mathrm{C}$ with an $\mathrm{OD}_{650}=1.1$ 

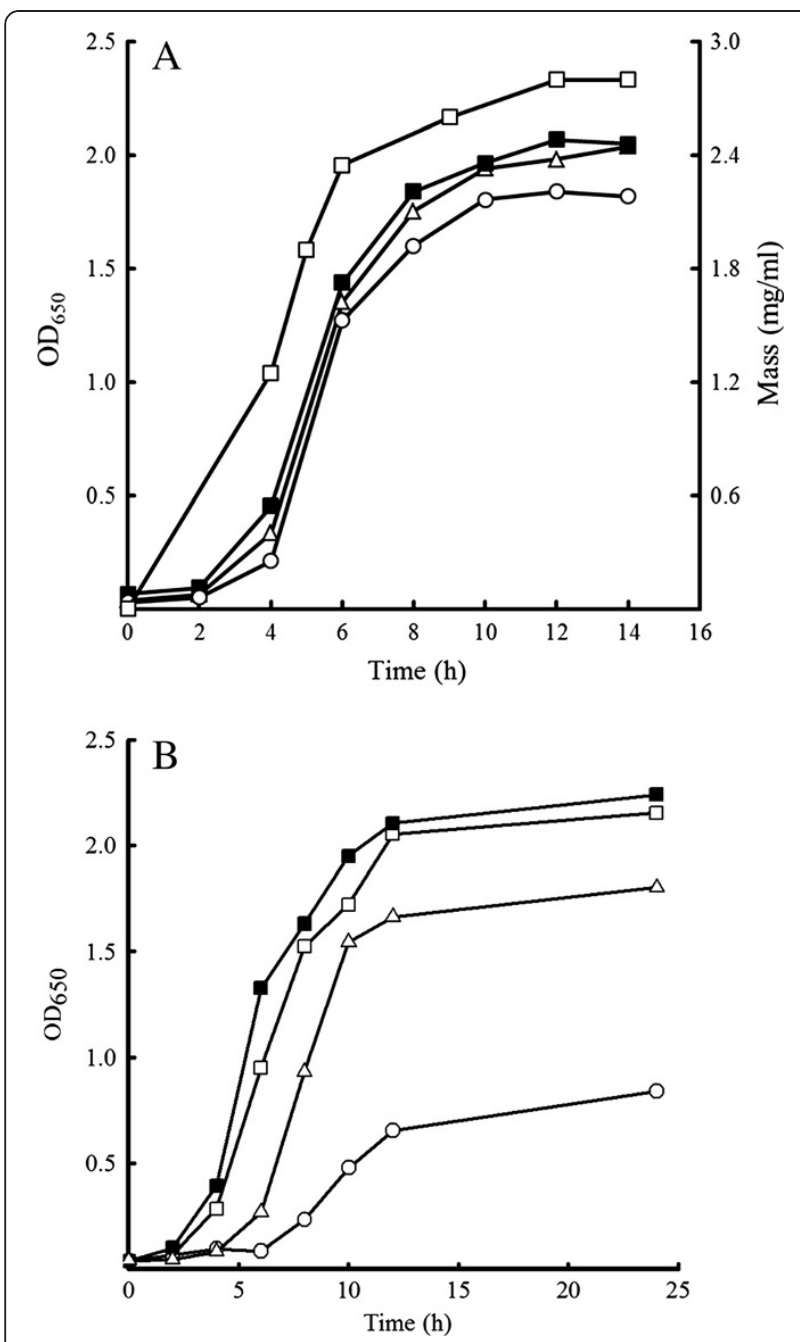

Figure 2 Growth of Streptomyces thermoviolaceus subsp. thermoviolaceus isolate 76T-2 in various media and different temperatures. (A) Growth curve of 76T-2 in UFO $(-\square-)$, UF $(-\Delta-)$, and $\mathrm{LB}(-\circ-)$ media at $45^{\circ} \mathrm{C}$. The cell mass $(-\square-)$ and $\mathrm{OD}_{650}$ values were measured at different time points as indicated. (B) Growth curve of $76 \mathrm{~T}-2$ at $45^{\circ} \mathrm{C}(-\mathbf{-}), 40^{\circ} \mathrm{C}(-\square-), 50^{\circ} \mathrm{C}(-\Delta-)$, and $30^{\circ} \mathrm{C}(-\circ-)$ in UF medium.

at $1 \mathrm{~h}$ and $\mathrm{OD}_{650}=0.05$ at $2 \mathrm{~h}$ and no further increses in PCL degradation afterward. However, when the temperature was changed to $30^{\circ} \mathrm{C}$, a slow $\left(\mathrm{OD}_{650}=1.1\right.$ after $1 \mathrm{~h}$ incubation) and gradual increase in PCL degradation rate with an $\mathrm{OD}_{650}=0.1$ at $14 \mathrm{~h}$ of incubation was observed. These results suggest that the optimal temperature for PCL degradation was $40^{\circ} \mathrm{C}$.

\section{Isolation of $\mathrm{PCL}$ depolymerases}

The PCL degradation enzymes were then isolated from culture supernatant of 76T-2 cells grown under optimal conditions. Solid ammonium sulfate was added to the supernatant. At $60 \%(\mathrm{w} / \mathrm{v})$ concentration, maximum protein precipitation was achieved. When the precipitate

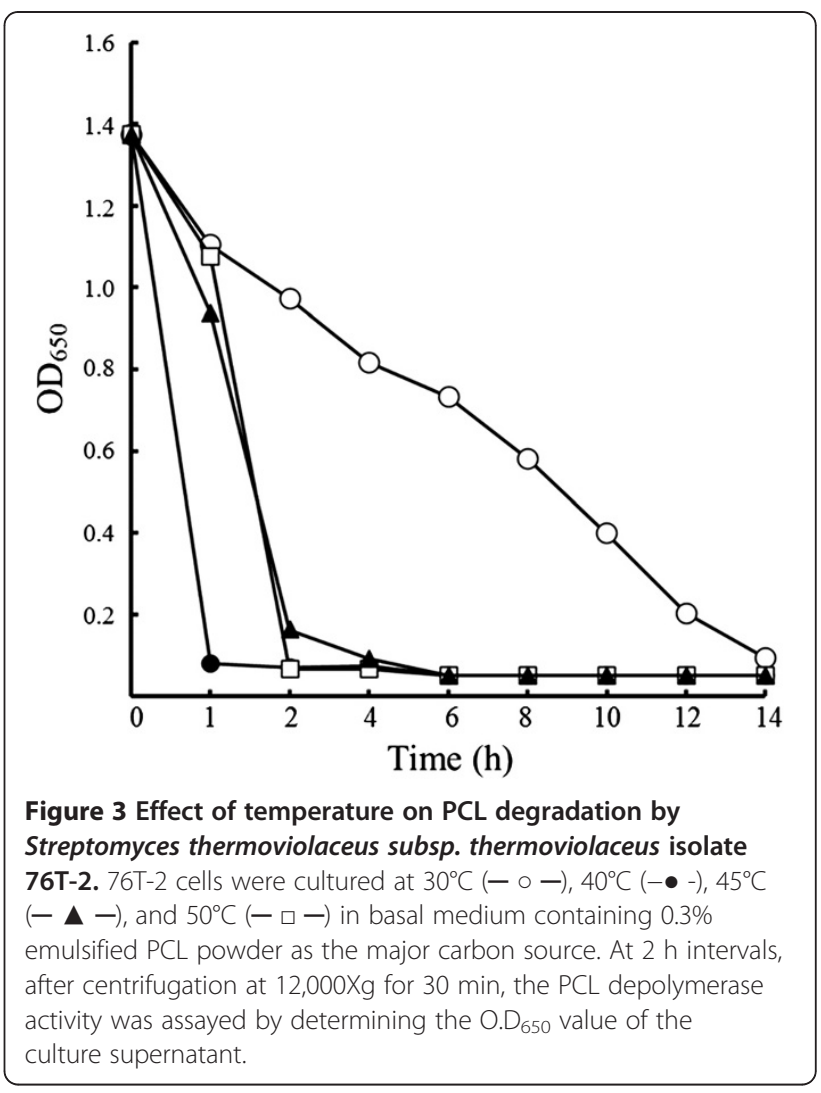

was analyzed by electrophoresis in an $8 \%$ native polyacrylamide gel, multiple protein bands were found (Figure 4A). Two bands of clear zone due to PCL hydrolysis were seen after performing a zymography by overlaying the gel on another $8 \%$ polyacrylamide gel containing PCL (Figure 4B, lane 1). The protein I and protein II with PCL depolymerase activity were eluted and electrophoresed on another $10 \%$ SDS polyacrylamide gel. Single bands with a molecular mass of approximately $55 \mathrm{kDa}$ (protein I) and $25 \mathrm{kDa}$ (protein II), respectively were observed (Figure 4C, lanes 1 and 2). The sequence of the first eight $\mathrm{N}$-terminal amino acid residues of the purified $25-\mathrm{kDa}$ PCL depolymerase was determined and found to be Ala-Asn-Phe-Val-ValSer-Glu-Ala. A similarity search of the DDJB sequence database indicated that this sequence was identical to amino acids $\mathrm{A}_{64}-\mathrm{A}_{71}$ of the Chi25 chitinase of Streptomyces thermoviolaceus OPC-520.

To investigate chitin degradation activity of the PCL depolymerases, the $60 \%$ ammonium sulfate precipitate was analyzed in an $8 \%$ native polyacrylamide gel and then overlaid on another gel containing chitin. A clear zone due to chitin hydrolysis was seen at the place corresponding to protein II (25-kDa protein) but not protein I (55-kDa protein) (Figure 4B, lane 2). This result indicated that the $25-\mathrm{kDa}$ PCL depolymerase secreted by $76 \mathrm{~T}-2$ also had the ability to degrade chitin, wheras the $55-\mathrm{kDa}$ protein was not capable of degrading chitin. 


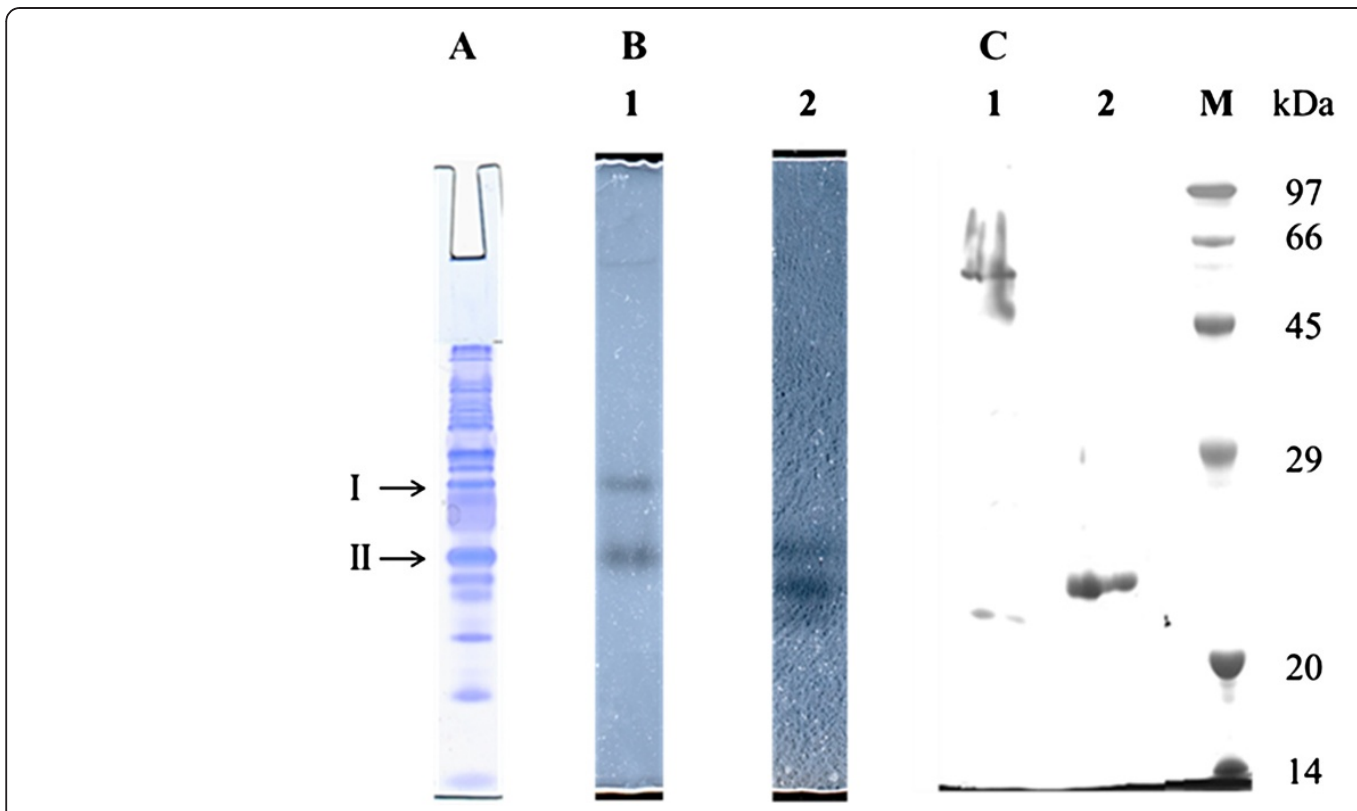

Figure 4 PAGE and zymography of ammonium sulfate precipitate of 76T-2 culture supernatant. Electrophoresis was carried out in a native $8 \%$ polyacrylamide gel (A). Zymography was performed by overlaying the gel on another native $8 \%$ polyacrylamide gel containing PCL (B1) or chitin (B2). The proteins in bands with enzymatic activity were isolated and electrophoresed in a 10\% SDS-polyacrylamide gel which was then stained with Coomassie brilliant blue R-250 (C): lane 1, purified 55-kda PCL depolymerase I; lane 2, purified 25-kda PCL depolymerase II.

\section{Discussion}

Polycaprolactone (PCL), an important polymer due to its strong mechanical properties, biodegradability, and miscibility with a number of other polymers (Kim and Rhee 2003, Labet and Thielemans 2009), has been investigated for its degradation in terrestrial and aquatic environments. A number of PCL-degrading bacterial and fungal strains of Alcaligenes, Clostridium, Aspergillus, Penicillium, Fusarium, and Streptomyces have been isolated (Tokiwa et al. 1976, Benedict et al. 1983a, 1983b, Tokiwa et al. 2009). In this study, we isolated a PCL-degrading bacterium from soil and identified it as Streptomyces thermoviolaceus subsp. thermoviolaceus based on its morphology, growth characteristics, and 16S rRNA gene sequence. This isolate was designated 76T-2. It grew well and formed clear zones on PCL emulsified agar plate at $45-50^{\circ} \mathrm{C}$ in one day, indicating that it is a fast-growing thermophile. Its PCL degradation ability was confirmed by demonstrating that the culture supernatant contained PCL-degrading enzymes.

Two PCL depolymerases of approximately 55 and $25 \mathrm{kDa}$ in size were detected. Although several extracellular PCL depolymerases have been isolaed (Murphy et al. 1996, Oda et al. 1997, Li et al. 2012), few of them have been fully characterized. Therefore, there is no previous report on the size range of bacterial or fungal PCL depolymerases. To our knowledge, this is the first report describing the characterization of a purified PCL depolymerase from a thermophilic Streptomyces. Based on its $\mathrm{N}$-terminal amino acid sequence and activity against chitin, we consider the $25 \mathrm{kDa}$ enzyme a chitinase with PCL-degrading activity.

PCL can be degraded by two types of esterases: One is lipase, and the other is cutinase. One example of lipase with PCL-degrading activity is the lipase from Alcaligenes faecalis (Oda et al. 1997). Cutinase is a serine hydrolase which breaks ester bonds in cutin. Fusarium is one example of bacteria producing such enzyme (Murphy et al. 1996). Chitin is a polymer of $\beta-1,4-\mathrm{N}$-acetylglucosamine in insects, crustaceans, fungi, and algae. The finding that the 25-kDa PCL depolymerase from 76T-2 had chitinase activity is novel as no other PCL depolymerases have been found to have such activity. Therefore, the 25-kDa enzyme isolated from 76T-2 may be a novel type of PCL depolymerase. Since isolate 76T-2 does not form clear zones on PHB-containing agar plate and there is no report that PCL depolymerases have PHA degrading activity, it is likely that the PCL depolymerases of 76T-2 do not degrade PHA.

Zymographic studies revealed another PCL depolymerase with a molecular mass of $55 \mathrm{kDa}$, and the purified $55-\mathrm{kDa}$ protein was able to degrade PCL. Although numerous attemps were made, we were unable to determine the $\mathrm{N}$-terminal amino acid sequence of this protein. Since the molecular mass of the Fusarium PCL depolymerase is $25 \mathrm{kDa}$ and that of lipases are larger (30 kDa) (Murphy et al. 1996), we focused our study on the $25-\mathrm{kDa}$ PCL depolymerase.

Four chitinases (Chi40, Chi35, Chi30 and Chi25) have been identified in Streptomyces thermoviolaceus OPC-520 
(Tsujibo et al. 1993). Based on amino acid sequence similarity of their catalytic domains, Chi40 and Chi30 are considered as members of family 18, and Chi35 and Chi25 are classified as family 19 of glycosyl hydrolases (Tsujibo et al. 2000b). Chi40 is the major chitinase of Streptomyces thermoviolaceus OPC-520 secreted into the culture medium. Since Chi25 and Chi35 are produced in very low levels, they are postulated to function as antifungal agents rather than as major enzymes to digest chitin (Tsujibo et al. 2000a). Genes encode for Chi25 and Chi35 have been cloned and found to be arranged in tandem. The deduced amino acid sequences of the catalytic domains of Chi25 and Chi35 are highly similar to each other. In addition to the catalytic domain, Chi35 has a N-terminal domain for polysaccharide binding (Tsujibo et al. 2000b) and sequences similar to certain domains of bacterial polymer-degrading enzymes such as xylanase I of $S$. thermoviolaceus OPC-520 (Tsujibo et al. 1997).

Although chitinases from many Streptomyces species have been extensively studied with respect to their structure, function, and regulation of gene expression (Saito et al. 1999, Kim et al. 2003, Saito et al. 2003, Okazaki et al. 2004, Yano et al. 2008, Hoang et al. 2011), few studies have been conducted on the degradation of biodegradable plastic by chitinases. In this study, we found that the $25-\mathrm{kDa}$ PCLdegrading enzyme is homologous to the chitinase (Chi25) of Streptomyces thermoviolaceus OPC-520 (GenBank accession number AB016843) (Tsujibo et al. 2000a, 2000b). Further study of the 25-kDa PCL-degrading enzyme from 76T-2 will advance our knowledge about the PCL depolymerases of $S$. thermoviolaceus.

\section{Competing interests}

The authors declare that they have no competing interests.

\section{Acknowledgements}

We thank Chao-Hung Lee for valuable discussions and critical editing of the manuscript. This study was supported by a grant (NSC99-2311-B-030-001MY3) from the National Science Council, Taipei, Taiwan.

\section{Author details}

'Department of Life Science, Fu Jen University, Hsin Chuang, Taipei, Taiwan. ${ }^{2}$ Bioresource Collection and Research Center, Food Industry Research and Development Institute, Hsinchu, Taiwan.

Received: 18 December 2012 Accepted: 17 January 2013 Published: 29 January 2013

\section{References}

Abou-Zeid DM, Muller RJ, Deckwer WD (2001) Degradation of natural and synthetic polyesters under anaerobic conditions. J Biotechnol 86:113-126

Abou-Zeid DM, Muller RJ, Deckwer WD (2004) Biodegradation of aliphatic homopolyesters and aliphatic -aromatic copolyesters by anaerobic microorganisms. Biomacromolecules 5:1687-1697

Benedict CV, Cameron JA, Huang SJ (1983a) Polycaprolactone degradation by mixed and pure cultures of bacteria and yeast. J Appl Polymer Sci 28:335-342

Benedict CV, Cook WJ, Jarrett P, Cameron JA, Huang SJ, Bell JP (1983b) Fungal degradation of polycaprolactones. J Appl Polymer Sci 28:327-334

Calabia BP, Tokiwa Y (2004) Microbial degradation of poly(D-3-hydroxybutyrate) by a new thermophilic streptomyces isolate. Biotechnol Lett 26:15-19
Chun J, Lee JH, Jung Y, Kim M, Kim S, Kim BK, Lim YW (2007) EzTaxon: a webbased tool for the identification of prokaryotes based on 16S ribosomal RNA gene sequences. Int J Syst Evol Microbiol 57:2259-2261

Federle TW, Barlaz MA, Pettigrew CA, Kerr KM, Kemper JJ, Nuck BA, Schechtman LA (2002) Anaerobic biodegradation of aliphatic polyesters: Poly(3hydroxybutyrate-co-3-hydroxyoctanoate) and poly(epsilon-caprolactone). Biomacromolecules 3:813-822

Hasegawa T, Takizawa M, Tanida S (1983) A rapid analysis for chemical grouping of aerobic actinomycetes. J Gen Appl Microbiol 29:319-322

Hoang KC, Lai TH, Lin CS, Chen YT, Liau CY (2011) The chitinolytic activities of Streptomyces sp. TH-11. Int J Mol Sci 12:56-65

Itoh T, Kudo T, Parenti F, Seino A (1989) Amended description of the genus Kineosporia, based on chemotaxonomic and morphological studies. Int J Syst Bacteriol 39:168-173

Kim DY, Rhee YH (2003) Biodegradation of microbial and synthetic polyesters by fungi. Appl Microbiol Biotechnol 61:300-308

Kim KJ, Yang YJ, Kim JG (2003) Purification and characterization of chitinase from Streptomyces sp. M-20. J Biochem Mol Biol 36:185-189

Klingbeil B, Kroppenstedt RM, Jendrossek D (1996) Taxonomic identification of Streptomyces exfoliatus $\mathrm{K} 10$ and characterization of its poly(3hydroxybutyrate) depolymerase gene. FEMS Microbiol Lett 142:215-221

Labet M, Thielemans W (2009) Synthesis of polycaprolactone: a review. Chem Soc Rev 38:3484-3504

Lechevalier MP, Lechevalier HA (1970) A critical evaluation of the genera of aerobic actinomcyetes. In: Prauser H (ed) The Actinomycetales. VES Gustav Fisher, Jena, pp 393-405

Lenz RW, Marchessault RH (2005) Bacterial polyesters: biosynthesis, biodegradable plastics and biotechnology. Biomacromolecules 6:1-8

Li F, Yu D, Lin X, Liu D, Xia H, Chen S (2012) Biodegradation of poly(epsiloncaprolactone) (PCL) by a new Penicillium oxalicum strain DSYD05-1. World J Microbiol Biotechnol 28:2929-2935

Murphy CA, Cameron JA, Huang SJ, Vinopal RT (1996) Fusarium polycaprolactone depolymerase is cutinase. Appl Environ Microbiol 62:456-460

Nakajima Y, Kitpreechavanich V, Suzuki K, Kudo T (1999) Microbispora coralline sp. nov., a new species of the genus Microbispora isolated from Thai soil. Int J Syst Bacteriol 49:1761-1767

Nakasaki K, Matsuura H, Tanaka H, Sakai T (2006) Synergy of two thermophiles enables decomposition of poly-epsilon-caprolactone under composting conditions. FEMS Microbiol Ecol 58:373-383

Nishida H, Tokiwa Y (1993) Distribution of poly(B-hydroxybutyrate) and poly(Ecaprolactone) aerobic degrading microorganisms in different environments. J Environ Polymer Degrad 1:227-233

Oda Y, Oida N, Urakami T, Tonomura K (1997) Polycaprolactone depolymerase produced by the bacterium Alcaligenes faecalis. FEMS Microbiol Lett 152:339-343

Okazaki K, Yamashita Y, Noda M, Sueyoshi N, Kameshita I, Hayakawa S (2004) Molecular cloning and expression of the gene encoding family 19 chitinase from Streptomyces sp J-13-3. Biosci Biotechnol Biochem 68:341-351

Ponsart S, Coudane J, Saulnier B, Morgat JL, Vert M (2001) Biodegradation of [H-3]poly(epsilon-caprolactone) in the presence of active sludge extracts. Biomacromolecules 2:373-377

Saito A, Fujii T, Miyashita K (2003) Distribution and evolution of chitinase genes in Streptomyces species: involvement of gene-duplication and domaindeletion. Antonie Van Leeuwenhoek 84:7-15

Saito A, Fujii T, Yoneyama T, Redenbach M, Ohno T, Watanabe T, Miyashita K (1999) High-multiplicity of chitinase genes in Streptomyces coelicolor A3(2). Biosci Biotechnol Biochem 63:710-718

Sanchez JG, Tsuchii A, Tokiwa Y (2000) Degradation of polycaprolcatone at $50^{\circ} \mathrm{C}$ by a thermotolerant Aspergillus sp. Biotechnol Letters 22:849-853

Shah AA, Hasan F, Hameed A, Ahmed S (2008) Biological degradation of plastics: a comprehensive review. Biotechnol Adv 26:246-265

Shirling EB, Gottlieb D (1966) Methods for characterization of Streptomyces species. Int J Sys Bact 16:313-340

Sinha VR, Bansal K, Kaushik R, Kumria R, Trehan A (2004) Poly-epsiloncaprolactone microspheres and nanospheres: an overview. Int J Pharm 278:1-23

Sun H, Mei L, Song C, Cui X, Wang P (2006) The in vivo degradation, absorption and excretion of PCL-based implant. Biomaterials 27:1735-1740

Tokiwa Y, Suzuki T (1977) Hydrolysis of polyesters by lipases. Nature 270:76-78

Tokiwa Y, Calabia BP (2004) Degradation of microbial polyesters. Biotechnol Lett 26:1181-1189 
Tokiwa Y, Calabia BP, Ugwu CU, Aiba S (2009) Biodegradability of plastics. Int J Mol Sci 10:3722-3742

Tokiwa Y, Ando T, Suzuki T (1976) Degradation of polycaprolactone by a fungus. J Ferm Technol 54:603-608

Tseng M, Hoang KC, Yang MK, Yang SF, Chu WS (2007) Polyester-degrading thermophilic actinomycetes isolated from different environment in Taiwan. Biodegradation 18:579-583

Tsujibo H, Hatano N, Endo H, Miyamoto K, Inamori Y (2000a) Purification and characterization of a thermostable chitinase from Streptomyces thermoviolaceus OPC-520 and cloning of the encoding gene. Biosci Biotechnol Biochemi 64:96-102

Tsujibo H, Minoura K, Miyamoto K, Endo H, Moriwaki M, Inamori Y (1993) Purification and properties of a thermostable chitinase from Streptomyces thermoviolaceus OPC-520. Appl Environ Microbiol 59:620-622

Tsujibo H, Ohtsuki T, lio T, Yamazaki I, Miyamoto K, Sugiyama M, Inamori Y (1997) Cloning and sequence analysis of genes encoding xylanases and acetyl xylan esterase from Streptomyces thermoviolaceus OPC-520. Appl Environ Microbiol 63:661-664

Tsujibo H, Okamoto T, Hatano N, Miyamoto K, Watanabe T, Mitsutomi M, Inamori Y (2000b) Family 19 chitinases from Streptomyces thermoviolaceus OPC-520: molecular cloning and characterization. Biosci Biotechnol Biochem 64:2445-2453

Yano S, Honda A, Rattanakit N, Noda Y, Wakayama M, Plikomol A, Tachiki T (2008) Cloning and expression of chitinase A gene from Streptomyces cyaneus SP27: the enzyme participates in protoplast formation of Schizophyllum commune. Biosci Biotechnol Biochem 72:1853-1859

doi:10.1186/2191-0855-3-8

Cite this article as: Chua et al: Degradation of Poly( $\varepsilon$-caprolactone) by thermophilic Streptomyces thermoviolaceus subsp. thermoviolaceus 76T-2. AMB Express 2013 3:8.

\section{Submit your manuscript to a SpringerOpen ${ }^{\circ}$ journal and benefit from:}

- Convenient online submission

- Rigorous peer review

- Immediate publication on acceptance

- Open access: articles freely available online

- High visibility within the field

- Retaining the copyright to your article

Submit your next manuscript at $\gg$ springeropen.com 